University for Business and Technology in Kosovo

UBT Knowledge Center

UBT International Conference

2017 UBT International Conference

Oct 28th, 11:00 AM - 12:30 PM

\title{
Higher Education in Algeria: Achievements and challenges- 1963 to 2017
}

\author{
Fatima Bouchikhi \\ University of Tlemcen \\ Barka Zine \\ University of Tlemcen, zine.barka@gmail.com
}

Follow this and additional works at: https://knowledgecenter.ubt-uni.net/conference

Part of the Education Commons

\section{Recommended Citation}

Bouchikhi, Fatima and Zine, Barka, "Higher Education in Algeria: Achievements and challenges- 1963 to 2017" (2017). UBT International Conference. 115.

https://knowledgecenter.ubt-uni.net/conference/2017/all-events/115

This Event is brought to you for free and open access by the Publication and Journals at UBT Knowledge Center. It has been accepted for inclusion in UBT International Conference by an authorized administrator of UBT Knowledge Center. For more information, please contact knowledge.center@ubt-uni.net. 


\title{
"Higher Education in Algeria: achievements and challenges - 1963 TO 2017"
}

\author{
Fatima Bouchikhi ${ }^{1}$, Zine Barka \\ ${ }^{1,2}$ GREFiP - University of Tlemcen \\ zine.barka@gmail.com
}

\begin{abstract}
The paper is based on the case study of the higher education sector in Algeria. Around the world higher education is under pressure to change. It is growing fast and its contribution to economic growth is vital. Universities are, mainly, expected to create knowledge; improve equity among population; and respond to student. Furthermore, it has been largely documented that in developing countries, higher education is recognized as a key force for modernization and development. Consequently, this has caused an increase in the demand for its access, accompanied by several challenges: students are more and more asking for quality education and decent jobs; the labor market is also looking for adapted and new skills more in line with the evolution of the production process. Government is, currently, faced with les resources to allocate to the sector which has been a top priority in the public policies implemented since independence in 1963.

Broadly speaking, Algeria's higher education sector has been marked by two major policy reforms since its independence. The most recent of these - the adoption of the three-cycle degree higher - education framework known as the "LMD System" (License / Bachelor -Master Doctorate) - has been in place since 2004 / 2005. "Massification" was a core part of both reforms, in part motivated by the demographic reality of a large youth population, but also by explicit policy choices undertaken by the government. The application of massification policies in Algeria led to a trend of favoring quantity over quality.

To accommodate what is called in Algeria - democratization of Higher Education - that is the increased number of registered students, there has been major achievements, particularly in terms of infrastructure.

In imitating European policies for higher education, policy makers in Algeria have focused on form and ignored substance.

The plan of the paper is organized as follows: the next section gives the legal framework of the tertiary education. The second section discusses an overview of the different stages of the development of higher education through the various policies during the period 1963 to 2017, followed by a comment on the major indicators of the sector in terms of infrastructure and human resources allocated to support the policies. The sources of funding will be reviewed to determine how important has been the policy of higher education in the development process. And the final part will deal with the main challenges of higher education in Algeria. How globalization is affecting the sector? can the public policy of higher education continue as it is with many subsidies or education expenditures? are to be reviewed to make them more efficient and in line with the current financial constraints. And finally, a conclusion will be offered at the end of this paper.
\end{abstract}

Keywords: Higher Education, Algeria, Education Policy, Tertiary Education.

Economists very often stress the link between education and economic growth. Investing in education is bound to increase economic growth, improve income distribution, and reduce 
poverty1. However, it is mentioned that to produce the expected positive effects on the economy, it should be mixed with a sound economic policy of education. Therefore, soon after independence in 1963, Algeria engaged in a progressive economic plan to develop its economy and bring prosperity and education for all the population.

The paper looks at higher education policies implemented since independence and tries to assess the outcomes of such high public expenditures allocated annually to the education sector. We conclude with some remarks on the main challenges facing higher education in Algeria bearing in mind the current limited financial situation after so many years of generous subsidies.

\section{The Legal Framework of the Tertiary Education}

Article 65 of the $1996^{2}$ Constitution provides the general framework of the higher education sector and specifically mentions:

- The right to education is guaranteed.

- Public education is free in the conditions set by the law.

- Basic education is mandatory.

- The State regulates the national education system.

- The State shall ensure equal access to education and vocational training.

Higher education is under the authority of a government minister, who prepares and implements government policy on higher education and scientific research.

I.1. Higher Education Public Institutions Missions, Organization and Functioning are defined by a set of legal text:

- Executive Decree ${ }^{\circ}{ }^{\circ}$ 03-279 of 23 August 2003 setting out the missions and specific rules for the organization and functioning of the university ${ }^{3}$.

- Executive Decree No. 05-299 of 16 August 2005 laying down the specific tasks and rules for the organization and functioning of the university center 4 .

- Executive Decree No. 16-176 of 14 June 2016 establishing the standard status of the higher school $^{5}$.

I.2. Higher Education Institutions Network is composed of:

A regional distribution is made in relation to the socio-economic network of the region, and the number of students. Algerian University Network accounts hundred and six (106) universities spread over forty-eight districts (48), covering the entire national territory. This network consists of fifty (50) universities, thirteen (13) university centers, twenty (20) national schools (Ecoles Nationales Supérieures ) and ten (10) schools - écoles supérieures-, eleven (11) écoles normales supérieures or Teacher training colleges and two (02) preparatory high schools - Ecoles Préparatoires: two in the Center and one in Oran, ${ }^{6}$ namely: the preparatory school in economics, trade and management in Kolea, the preparatory school to the science and Techniques of Algiers and the preparatory school in Biology of Oran.

${ }^{1}$ MENA Development Report - The Road Not Traveled - Education Reform in the Middle East and North Africa - 2008 The International Bank for Reconstruction and Development / The World Bank

${ }^{2}$ Algerian Gazette $\mathrm{N}^{\circ} 76$ du 8 décembre 1996, modifiée by the 2016 Constitution, Law n ${ }^{\circ}$ 16-01 March 6, 2016 -Algerian Gazette ${ }^{\circ} 14$ dated March 7, 2016

${ }^{3}$ Algerian Gazette 2003, ${ }^{\circ}$ 51, pages 4 - 13, amended and supplemented by decree Executive Order No. 06-343 of 27 September 2006 (Algerian Gazette Year 2006, No. 61, pages 21-22)

${ }^{4}$ Algerian Gazette 2005, No. 58, pages 3 - 10

${ }^{5}$ Algerian Gazette year 2016, No. 36, pages 9-16

6https://www.mesrs.dz/universites 
The University of Continuing Education (Université de la Formation Continue - UFC), which was created by a decree in $1990^{7}$, enables those who did not successfully pass the baccalaureate (high school) degree to enroll in one of these higher education centers distributed throughout the national territory.

The role of the Ecoles Normales Supérieures is to train primary and secondary teachers. The number of students attending institutions of higher education is approximately 1210000 (aggregate figure for all three cycles and continuing education) and 60\% are female.

\section{3. Funding Education}

Middle East and North Africa countries on average spend more than 20 percent of their budget to education. The nongovernment financial contribution to education is difficult to discern in MENA, as few data are available. However, there is a widespread belief that this contribution is modest. In part, this is because enrollment in private education tends to be very low in some countries, for example, in Tunisia and in Algeria ${ }^{8}$.In addition, most governments in MENA have followed a policy of essentially free education at all levels of public education and Algeria is among them. Usually, university students pay a symbolic fee, which covers an insignificant proportion of outlays.

\section{I.4. Financial Support to Students}

A very generous policy of student support has been put in place since independence and is based on three channels:

indirect, financial support in the form of accommodation, food, medical services and socioeducational services and facilities. Every student who lives more than $50 \mathrm{~km}$ away from the institution has access to accommodation in the halls of residence;

- direct financial support for students from families with limited resources (student grant);

- the "Excellence-Major programme" enables the best students to compete for an overseas scholarship. A total of $85 \%$ of Algerian students receive grants and more than $50 \%$ are accommodated by the National University Student Services Office (ONOU).

\section{I.5. University - Industry Cooperation}

Scientific Research, a national priority in the education policy is defined by a legal framework 9 . Its target is to set up links between scientific research carried out in universities and the industrial sector to promote the country's economic development. It aims also at disseminating knowledge, master of technology, promotion of research and development (R\&D).

II. An Overview of the Different Stages of the Development of Higher Education Until independence, on July 5, 1962, the university programs were only aimed at a French colonial elite. The Algerian component was tiny. The number of students at the University of Algiers, which dates to 1909, and its annexes Oran and Constantine, was barely 500 (1960/61) for a local population of nearly eight million.

7Executive Decree No. 90-149 of 2 May 26, 1990 on creation, organization and functioning of the training University continues (Algerian Gazette year 1990, no. 22, pages 635-639) and the Executive Decree No. 90-150 of 26 May 1990 on the establishment of continuing training centers (Algerian Gazette 1990, No. 22, pages 639).

8The Minister of Higher Education and Scientific Research revealed recently that three universities have just obtained the licenses to open as soon as the academic year 2017-18. They will offer 1,000 educational places.

${ }^{9}$ Act of 4 April 1999, as amended and extended by the Act of 23 February 2008 
At independence, Algeria gradually embarked on a vast training program at all levels to face the vacuum created after the mass departure of the French settlers.

By the Constitution, schooling is free and compulsory for all and with access to higher education for the greatest number. This decision is likely to have consequences, such as the need to build sufficient schools, colleges, and universities, to train enough teachers to realize the fundamental principles of universality, equality and equity in education through access for all to free and compulsory education. The number of students in the Algerian University of today with more than 1 million students is dispersed throughout the national territory in 90 institutions. The evolution of the Algerian university system, in its organization and its curricula, has had four essential stages since independence:

- The first stage, very short, was the continuation of the old system that prevailed.

- The second stage (1971-1984) corresponds to the implementation of the first reform of the higher education system of 1971, followed by the introduction of the university map of 1982, updated in 1984. The requirements of the economic development model, which began with the launching of the first three-year plan in 1967, required a profound overhaul of the higher education. Indeed, the industrialization scheme conceived for the development of the national economy induced important needs in management. A new orientation and new missions are defined and assigned to the higher education system. Thus, several measures will be implemented to ensure a better match between higher education and the needs of the economy.

- The third period is the consolidation of the education system as defined by Act No. 9905 of 4 April 1999 laying down the Higher Education Guidance Act. This law summarizes the overall regulatory framework produced since independence and gives it an overall coherence.

- Finally, the last step is the implementation of the universal system LMD - Licence Master - Doctorate, launched in 2004 and which corresponds to the implementation of a new architecture in the education offer. The higher education offer is divided now into three levels, each corresponding to a Bachelor, a Master's degree and a PhD.

II.1. Main Achievements of the Reforms

Through these reforms, four major challenges have been identified:

II.1.1. The Democratization of Access to University

Democratization or "massification" is fostered by free access to higher education and the existence of university services such as dormitory, restaurants for students which have made it possible to benefit at a very low cost to higher education for the greatest number of students. This policy concerned all young students from all social categories, regions and localities of the country. The feminine element was the first beneficiary of this policy.

II.1.2. «Algerianisation»

As soon as the country's independence was proclaimed, the "Algerianization" of the education system had become a concern. The target was to adapt the educational programs to the new economic policy needs, i.e., the replacement of foreign teachers. At the beginning of the academic year 1962-1963, 82 Algerians, mainly assistants, were to be counted among the faculty, out of a total of 298 teachers in office.

II.1.3. "Arabization"

At Independence, higher education was faced with a large deficit of teachers who mastered the Arabic language, which resulted in an important call for cooperation with the Arab world.

II.1.4. Enrollment Growth and Infrastructure Densification 
In 1961 the total number of Algerians enrolled in higher education institutions was 1,317 students enrolled at the University of Algiers and in the annexes of Oran and Constantine. At the start of 2010/11, the number of students enrolled, fifty years after independence, reached 1,200,000 distributed among several university sites located in the 48 districts called "Wilayates" or districts. To absorb these growing flows of new students, a major program of university infrastructure, teaching staff, and socio-academic support was launched and carried out. University students have access to various services and benefits; among them housing, meals, health care, wellbeing as well as sports.

II.1.5. Strong Growth of the Female Students

The share of women in total enrollment increased from 23 per cent in 1972 to 50 per cent in 2000. From then on, the female component continued to increase steadily, reaching 59 per cent in 2010.

II.1.6. Field of Study by Higher Education Students

The proportion of enrollment in university in science and engineering versus humanities and social sciences is noticeable when we analyze the data. This pattern has started to change slightly to introduce a more balanced distribution of students.

III. Current Challenges and Needs

The main challenge currently facing Algerian universities is how to reconcile the needs of democratic access to higher education with the need for higher quality of training in a changing world characterized by the advent of a knowledge and information society and economic globalization ${ }^{10}$. Furthermore, one of the strategic challenges is to train to a high standard the large numbers of teachers needed to look after a student body estimated to be 1500000 strong. Another challenge for the policy makers in the field of higher education and scientific research is to establish an efficient high-quality system of training and research. Algeria has made throughout the years considerable efforts resulting in the extension of the university network along many research centers, now it is important to establish a closer link between university and the practical needs of the labor market if we want to reduce the youth unemployment particularly among the skilled population.

\section{References}

1. The International Bank for Reconstruction and Development / The World Bank MENA Development Report - The Road Not Traveled - Education Reform in the Middle East and North Africa (2008)

2. Z. Barka and A. Massaoudi "The Challenges of Higher Education in Algeria and the Prospects for Change" Algerian Journal of Public Finance, No.5, (2015) 12-14. 